(C) 2019 by the Arizona Board of Regents on behalf of the University of Arizona. This is an Open Access article, distributed under the terms of the Creative Commons Attribution licence (http://creativecommons. org/licenses/by/4.0/), which permits unrestricted reuse, distribution, and reproduction in any medium, provided the original work is properly cited.

\title{
EXTRACTION OF DISSOLVED ORGANIC CARBON FROM GLACIER ICE FOR RADIOCARBON ANALYSIS
}

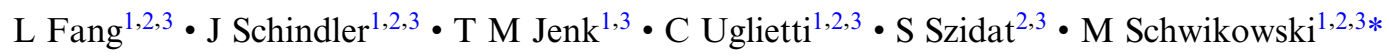 \\ ${ }^{1}$ Laboratory for Environmental Chemistry, Paul Scherrer Institute, CH-5232 Villigen PSI, Switzerland \\ ${ }^{2}$ Department of Chemistry and Biochemistry, University of Bern, CH-3012 Bern, Switzerland \\ ${ }^{3}$ Oeschger Centre for Climate Change Research, University of Bern, CH-3012 Bern, Switzerland
}

\begin{abstract}
Alpine glaciers are valuable archives for the reconstruction of human impact on the environment. Besides dating purposes, measurement of radiocarbon $\left({ }^{14} \mathrm{C}\right)$ content provides a powerful tool for long-term source apportionment studies on the carbonaceous aerosols incorporated in ice cores. In this work, we present an extraction system for ${ }^{14} \mathrm{C}$ analyses of dissolved organic carbon (DOC) in ice cores. The setup can process ice samples of up to $350 \mathrm{~g}$ mass and offers ultra-clean working conditions for all extraction steps. A photo-oxidation method is applied by means of external UV irradiation of the sample. For an irradiation time of $30 \mathrm{~min}$ with catalyzation by addition of $\mathrm{Fe}^{2+}$ and $\mathrm{H}_{2} \mathrm{O}_{2}$, we achieve an efficiency of $96 \pm 6 \%$ on average. Inert gas working conditions and stringent decontamination procedures enable a low overall blank of $1.9 \pm 1.6 \mu \mathrm{g} \mathrm{C}$ with a $\mathrm{F}^{14} \mathrm{C}$ value of $0.68 \pm 0.13$. This makes it possible to analyze the DOC in ice samples with a carbon content of as low as $25 \mu \mathrm{g} \mathrm{C} \mathrm{kg}^{-1}$ ice. For a first validation, the new method was applied to ice core samples from the Swiss Alps. The average DOC concentration and $\mathrm{F}^{14} \mathrm{C}$ values for the Fiescherhorn ice core samples show good agreement with previously reported data for the investigated period of 1925-1936 AD.
\end{abstract}

KEYWORDS: dissolved organic carbon, ice core, method development, UV oxidation.

\section{INTRODUCTION}

For meaningful interpretation of the recorded signals in ice cores from glacier archives, accurate dating is essential. Radiocarbon $\left({ }^{14} \mathrm{C}\right)$ is a powerful tool for dating and is widely applied in different fields (Libby 1954; Stuiver and Suess 1966; Reimer et al. 2013). For ice cores from high-alpine glaciers ${ }^{14} \mathrm{C}$-dating is particularly valuable for the ice in the bottom part, where strong thinning of annual layers prevents the use of annual layer counting or the assignment of reference horizons for dating (Thompson et al. 1998; Schwikowski et al. 1999a). The ${ }^{14} \mathrm{C}$ half-life of $5730 \mathrm{yr}$ allows covering the typical age range of alpine ice cores. ${ }^{14} \mathrm{C}$ dating of water insoluble organic carbon (WIOC) from glacier ice has been well established. Samples of $10 \mu \mathrm{g}$ WIOC can now be dated with reasonable uncertainty, requiring less than $1 \mathrm{~kg}$ of ice from typical mid-latitude and low-latitude glaciers (Jenk et al. 2007, 2009; Sigl et al. 2009; Uglietti et al. 2016). However, the low WIOC concentration in glaciers remote from sources, e.g. glaciers in the polar regions, puts a limit to this application. Because the concentrations of dissolved organic carbon (DOC) are around a factor 5 higher (10-100 ppbC, Legrand et al. 2013a, 2013b), using this fraction promises to allow an extension of this approach to new sites and generally reducing the achievable analytical (dating) uncertainty.

In addition to dating, ${ }^{14} \mathrm{C}$ has proved to be a powerful tool for source apportionment studies, i.e. to distinguish biogenic and fossil source contributions (Szidat et al. 2006; Zhang et al. 2012). Alpine ice cores allow access to continuous records of atmospheric pollution back to the preindustrial era in the regions where the majority of humans live (Schwikowski et al. 1999b; Eichler et al. 2012, 2015). A first long-term trend in concentrations separated into the contribution from fossil fuel and biogenic sources of atmospheric organic carbonaceous

*Corresponding author. Email: margit.schwikowski@psi.ch. 
particles was reconstructed from an ice core at the Fiescherhorn glacier (Swiss Alps; Jenk et al. 2006). In contrast to WIOC, which mainly consists of primary organic aerosol from direct emissions, water soluble organic carbon (WSOC) originates in large part from secondary organic aerosols (SOAs) formed in the atmosphere from volatile organic precursor compounds (Gelencsér et al. 2007). WSOC is a major fraction of organic aerosols in the atmosphere; however, its sources are not well constrained (Pio et al. 2007). WSOC in snow and ice is only one part of the DOC which is analyzed and additionally contains gaseous organics taken up during snowfall (Legrand et al. 2013b). Studying DOC along with its ${ }^{14} \mathrm{C}$ content in samples from ice cores will allow additional insight into historical natural and anthropogenic contributions to the organic carbon content of atmospheric aerosols.

Only very few long-term records of DOC concentrations, and even fewer in combination with the ${ }^{14} \mathrm{C}$ content, exist to date. To our knowledge all of these records were derived from ice cores (Preunkert et al. 2010; Legrand et al. 2013b; May et al. 2013). For studies of DOC in ice cores, one of the major limitations is the rather large demand of sample amount along with relatively low extraction efficiency and the threat of sample contamination (Preunkert et al. 2010; Legrand et al. 2013b; May et al. 2013). With the current state of the art of ${ }^{14} \mathrm{C}$ analysis with accelerator mass spectrometry (AMS) that allows the direct measurement of gaseous $\mathrm{CO}_{2}$ samples, carbon sample masses of as low as $3 \mu \mathrm{g}$ are sufficient (Ruff et al. 2007). Still, this translates to typical ice sample masses of several hundred grams for $\mathrm{DO}^{14} \mathrm{C}$ analyses. However, preceding AMS analysis, DOC has to be oxidized to $\mathrm{CO}_{2}$. In contrast to hightemperature combustion or wet-chemical oxidation techniques, the use of ultraviolet (UV) photochemical oxidation has the advantage of being suitable for large volumes of sample with low carbon content (Beaupré et al. 2007). It was applied by Singer et al. (2012) to determine the $\mathrm{DO}^{14} \mathrm{C}$ content of ice samples from different glaciers in the European Alps. However, their method has a limited carbon yield of 50\% (Steier et al. 2013). May (2009) and May et al. (2013) developed a setup for ${ }^{14} \mathrm{C}$ microanalysis of glacier ice and applied it to several ice core samples, but unexpected super-modern ${ }^{14} \mathrm{C}$ values led to inconclusive results. It should be noted that a straightforward analysis of DOC is challenging due to its vulnerability to contamination (Legrand et al. 2013a). Ice cores can potentially be contaminated during drilling, storage, and sample processing. Besides, DOC consists of a large part of mono- and di-carboxylic acids that are ubiquitous in ambient and laboratory air (Legrand et al. 2013b). Therefore, it is vital to ensure ultra-clean sample preparation and extraction with a low and stable process blank for reliable ${ }^{14} \mathrm{C}$ analysis of DOC. Here, we present such an approach with a new extraction setup for DOC concentration and ${ }^{14} \mathrm{C}$ analysis in low-concentration ice core samples. Our extraction system is designed for samples with volumes of up to $\sim 350 \mathrm{~mL}$ and concentrations as little as $25 \mathrm{ppbC}$ DOC (equals to $25 \mu \mathrm{g} \mathrm{C} \mathrm{kg}^{-1}$ ice).

\section{EXPERIMENTAL}

\section{Extraction Setup}

Figure 1 shows an overview scheme of the complete DOC extraction setup (Schindler 2017). This setup allows handling of the entire sample treatment under inert gas conditions $(\geq 99.999 \%$ helium gas, further purified by a homemade getter oven) in order to extract carbon masses of as little as a few micrograms, while aiming to avoid potential contamination during analysis. The getter oven consists of an insulated, resistively heated Inconel (a high temperature resistant nickel-chromium-based super-alloy) tube filled with $15 \mathrm{~g}$ tantalum wire. Helium is used as carrier gas in the entire setup. Furthermore, all parts in contact with the sample when in its 


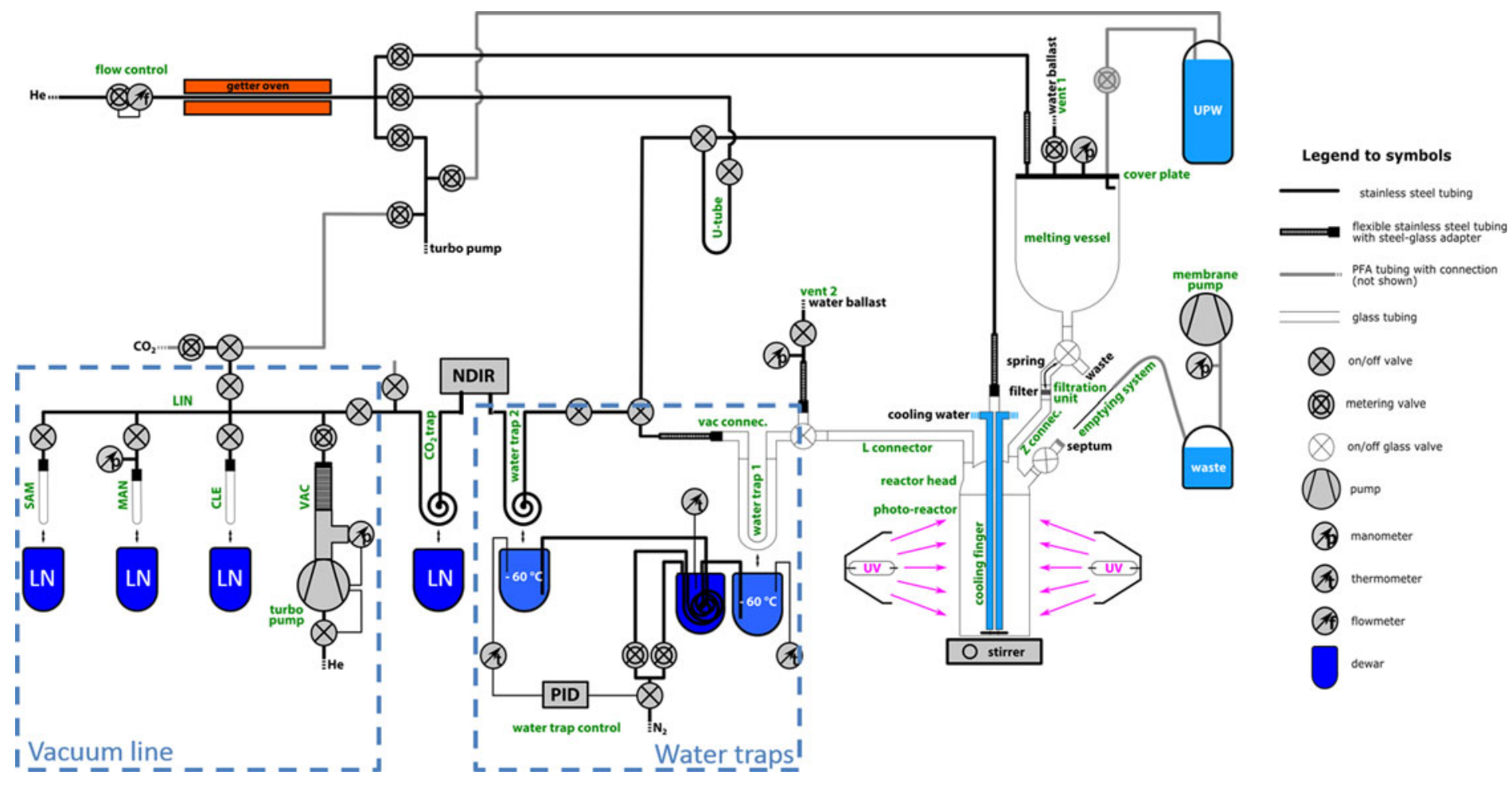

Figure 1 Schematic of the complete DOC extraction setup. Green text labels individual components. UPW (ultra-pure water), LN (liquid nitrogen), NDIR (CO2 detector), LIN (vacuum manifold), VAC (pump manifold), CLE (cleaning tube), MAN (manometry cell), SAM (sampling tube). 

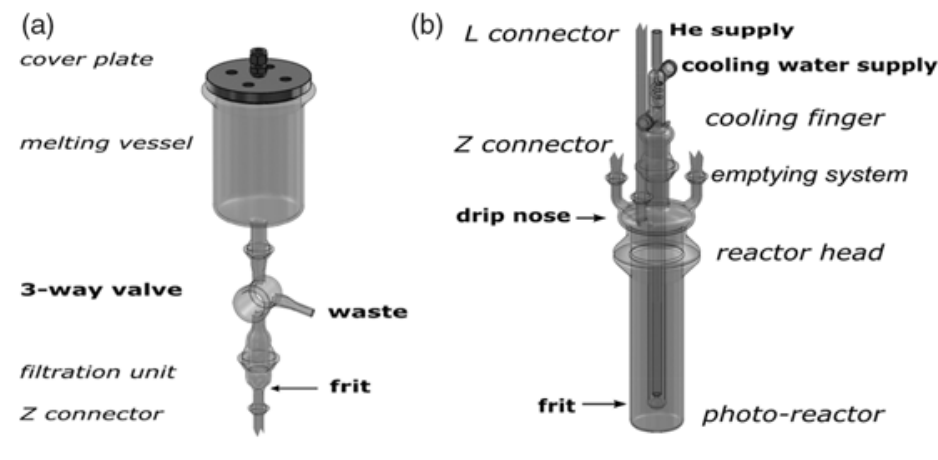

Figure 2 View of (a) melting vessel, filtration valve and filtration unit, (b) the photo-reactor, reactor head and cooling finger. Italic text refers to the labeling introduced in Figure 1, bold text refers to connections or emphasizes special features.

liquid form were fabricated modularly from either glass or quartz glass to allow thorough cleaning and reduction of memory effects compared to stainless steel. To minimize outgassing or out-washing of organic carbon into the sample, no lubricants are used. The major system components, highlighted in green text in Figure 1, are described in detail in the following:

The glass melting vessel (custom made by GlasKeller AG, Switzerland) with an inner diameter with an inner diameter of $100 \mathrm{~mm}$ has a volume of around $1.3 \mathrm{~L}$ (Figure 2a). A support holds the vessel and fixes the stainless steel cover plate to the vessel by spring tension. The flange connection is sealed by a PFA coated O-ring. As illustrated in the sketch, the cover plate gives access to four thread connectors ( $1 / 4$ inch): (1) the helium supply, (2) a metering valve (SS-BNTS6MM, Swagelok, USA) with a bubble counter (GlasKeller AG, Switzerland) that acts as a vent with water ballast (vent 1), (3) a manometer for pressure monitoring (PBMN-25B11AA14402201000, Baumer Electric AG, Switzerland), and (4) the ultra-pure water (UPW) supply. The UPW dispenser system consists of a glass bottle filled with UPW (Sartorius, $18.2 \mathrm{M} \Omega \times \mathrm{cm}$ ) and connected by PFA tubes to both the helium supply and the cover plate. Applying pressure via the helium supply allows pushing the desired amount of UPW to the melting vessel.

The filtration unit is shaped as an adapter piece from glass spherical joint (SJ) 41/25 to SJ 19/7 (Figure 2a). In the center, an 8-mm-diameter frit (160-250 $\mu \mathrm{m})$ acts as support for a pre-cleaned quartz fiber filter that was baked at $800^{\circ} \mathrm{C}$ for $2 \mathrm{hr}(20 \mathrm{~mm}$ diameter, PALLFLEX Tissuquartz, 2500QAO-UP) and fixed onto the frit by a metal spring. The filter used for the separation of POC from the liquid sample is similar to the procedure for $\mathrm{WIO}^{14} \mathrm{C}$ analysis described in Jenk et al. (2006). However, in contrast to the commonly used lab filtration unit described therein, this setup allows filtration under inert gas conditions, avoiding potential sample contamination from take-up and mixing of ambient air with the liquid sample during the filtration step.

The photo-reactor is a cylindrical quartz glass vessel (Qsil GmbH, Germany) (Figure 2b), and allows introduction of the filtered solution via a glass connector ( $\mathrm{Z}$ connector). In the center of the reactor head, the cooling finger is inserted via a glass SJ 41/25 connection and reaches close to the base of the photo-reactor. The cooling finger has several functions and is constructed 
from three concentric glass tubes. The inner tube is connected to the helium supply. The outer two tubes serve for cooling water circulation in the cooling finger and in combination with external cooling of the photo-reactor by air ventilation is essential to control the sample temperature during photo-oxidation. For sample mixing, the promotion of homogeneous oxidation and efficient degassing, a magnetic stirrer is used. The magnetic stir bar is encapsulated in glass to avoid contamination (Beaupré et al. 2007). Two UV lamps (MH-Module 250W Hg XL, Heraeus, Germany) are installed opposite of each other and enclose the reactor in a distance of $3 \mathrm{~cm}$ to the reactor walls. A box surrounds the UV lamps and reactor to prevent user-exposure to UV irradiation and ozone. This protection box further enhances the photon-yield because of its reflective aluminum construction. The emptying system consists of a long stainless steel needle, a glass bottle, and a membrane pump. For sample removal the stainless steel needle is introduced through a septum to the reactor and the sample is pumped out with a membrane pump.

Despite cooling with the cool finger, the liquid sample heats up to around $50^{\circ} \mathrm{C}$ during $\mathrm{UV}$ irradiation, resulting in an enhanced content of water vapor. For water removal, two cryogenic water traps are therefore added in front of the $\mathrm{CO}_{2}$ trap that is cooled with liquid nitrogen (LN). Water trap 1 (Figure 1) is a U-shaped glass tube $(20 \mathrm{~cm}$ length, 10 $\mathrm{mm}$ inner diameter) filled with glass capillaries and water trap 2 is made from stainless steel tube bent to a coil ( $2 \mathrm{~m}$ length, $1 / 4$ inch outer diameter [OD], Swagelok). A PID temperature controller (Eurotherm Produkte AG, Switzerland) is used to stabilize both water traps at $-60^{\circ} \mathrm{C}$ by a controlled nitrogen gas transfer from a $\mathrm{LN}$ reservoir into the Dewar around the water traps, similar in principle to the system described in Jenk et al. (2016).

All components of the vacuum line (indicated as blue dashed box in Figure 1) are made from stainless steel tubes $(1 / 4$ inch OD) and stainless steel fittings (Swagelok) allowing operation at high vacuum of about $10^{-7}$ mbar. A turbo-molecular pump (HiCube 80 Eco, Pfeiffer Vacuum $\mathrm{AG}$, Germany) is connected to the vacuum line through a dosing valve (SS-6BMRG-MMSC11, Swagelok). The vacuum line for $\mathrm{CO}_{2}$ sample purification and collection is similar to the one described in Szidat et al. (2004) and consists of a cleaning tube for $\mathrm{CO}_{2}$ purification ("CLE," glass tube, $200 \mathrm{~mm}$ length, $8 \mathrm{~mm}$ OD) with a removable ethanol-dry ice cooling bath $\left(-72^{\circ} \mathrm{C}\right)$, the manometry cell ("MAN," glass tube, $150 \mathrm{~mm}$ length, $6 \mathrm{~mm}$ OD) with a removable $\mathrm{LN}$ bath $\left(-196^{\circ} \mathrm{C}\right)$ and connected to a pressure gauge for $\mathrm{CO}_{2}$ quantification (Baumer Electric AG), and the sampling tube for $\mathrm{CO}_{2}$ transfer and sample flame sealing ("SAM," glass tube, $150 \mathrm{~mm}$ length, $4 \mathrm{~mm}$ OD) connected to the vacuum line by a steel-glass adapter (homemade) to allow easy removal and replacement.

\section{Sample Preparation and Decontamination}

Prior to the extraction of DOC from ice samples and subsequent ${ }^{14} \mathrm{C}$ analyses, several steps are required. First, ice samples are cut and decontaminated by removing $5 \mathrm{~mm}$ from the surface using a band saw in a cold lab $\left(-20^{\circ} \mathrm{C}\right)$. Ice samples are then transferred in pre-cleaned PETG containers (1000 mL, Semadeni, Switzerland; soaked three times overnight in UPW) from the cold room to the analytical laboratory. After tempering in the laboratory, ice blocks are inserted into the melting vessel, which is closed and then flushed with helium during rinsing of the ice block with UPW to remove approximately $20 \%$ of the ice volume, with the rinsing water then being discarded through the waste outlet (Figure 2a). 


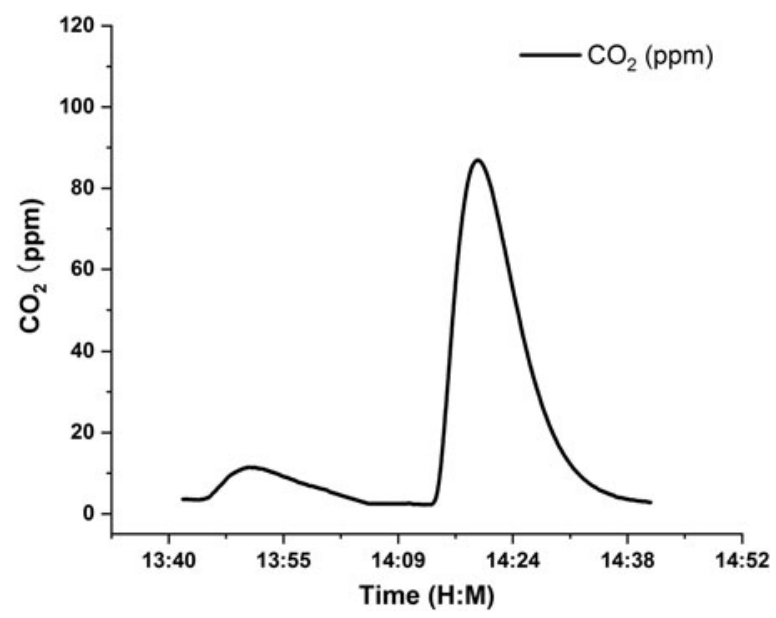

Figure 3 Typical NDIR $\mathrm{CO}_{2}$ scan of the decontamination step (first peak) followed by the oxidation of a $5 \mu \mathrm{M}$ sodium acetate standard solution (Sigma-Aldrich, No. 71180) at a helium flowrate of $100 \mathrm{~mL} / \mathrm{min}$.

Before introducing a sample, the DOC extraction setup is decontaminated by running a procedure to remove potential sources of carbon contamination: After flushing the vacuum line with helium and zeroing the nondispersive infrared $\mathrm{CO}_{2}$ detector (NDIR, LI-820A, LI-COR, USA, modified to allow in-line operation by improved connection seals), the glass setup is pressurized with helium slightly above atmospheric pressure (1.04 bar) to create the inert gas atmosphere. In the next step, the melting vessel is filled with about $50 \mathrm{~mL}$ UPW, which is subsequently drained to the photo-reactor to remove potential contamination from the melting vessel, quartz fiber filter, and reactor glass surfaces. $1 \mathrm{~mL}$ of $85 \% \mathrm{H}_{3} \mathrm{PO}_{4}$ (Merck KGaA) is then added via a septum into the reactor using a glass syringe to acidify the water $(\mathrm{pH} \sim 1)$ while it is continuously purged with helium to remove dissolved $\mathrm{CO}_{2}$ and the $\mathrm{CO}_{2}$ evolving from the solvation of inorganic carbon (IC). To enhance the oxidation efficiency, $2 \mathrm{~mL}$ of $100 \mathrm{ppm} \mathrm{FeSO}_{4}$ (ACS reagent, $\geq 99.0 \%$, Sigma-Aldrich) and $1 \mathrm{~mL}$ of $50 \mathrm{mM} \mathrm{H} \mathrm{O}_{2}(\geq 30 \%$, Sigma-Aldrich) are additionally injected into the reactor (Hsueh et al. 2005; Kušić et al. 2006). With the reactor also being irradiated with UV light, this cleaning process is monitored by continuous measurement of the emerging $\mathrm{CO}_{2}$ being flushed through the NDIR $\mathrm{CO}_{2}$ detector by the helium carrier (flow rate $100 \mathrm{~mL} / \mathrm{min}$ ). Once the $\mathrm{CO}_{2}$ signal drops asymptotically below a set threshold, indicating that cleaning is finished, the UV lamps are turned off. In Figure 3, a typical $\mathrm{CO}_{2}$ detector scan is shown.

\section{DOC Extraction}

After the ice has been rinsed, it is melted, thereby slightly enhancing the melt rate by heating with an infrared lamp and a hot air gun. The liquid sample is then transferred from the melting vessel to the photo-reactor passing a quartz fiber filter, both pre-cleaned as described earlier. To keep the filter in place, it is fixed with the help of a stainless steel spring, the only metal part in contact with the liquid sample. Filtration is performed at inert gas conditions, always preserving a little overpressure to prevent ambient air from leaking into the setup. After transfer, the sample volume is determined by measuring the reactor fill level. By mixing with the previously cleaned solution, the filtrate gets acidified. After the degassing of $\mathrm{CO}_{2}$ 
from IC, again $1 \mathrm{~mL}$ of $50 \mathrm{mM} \mathrm{H}_{2} \mathrm{O}_{2}$ is injected into the reactor right before the UV irradiation is started. During UV oxidation, $\mathrm{CO}_{2}$ is continuously degassed by the helium carrier gas stream and led through three cryogenic traps (Figure 1). The first two traps (water trap $1 \& 2$ ) operate at $-60^{\circ} \mathrm{C}$ and retain water vapor, while a further cryogenic trap in a $\mathrm{LN}$ bath $\left(\mathrm{CO}_{2}\right.$ trap) is used to freeze out the $\mathrm{CO}_{2}$ from the carrier gas stream. Once the oxidation has finished, as monitored by the $\mathrm{CO}_{2}$-detector (see Figure 3), the cryogenic trap is isolated and evacuated to remove helium and volatile gases while still being cooled by $\mathrm{LN}$ to keep the $\mathrm{CO}_{2}$ sample frozen. After subsequent cryotransfer of the sample $\mathrm{CO}_{2}$ to the CLE with LN, the CLE is closed-off towards the vacuum and the vacuum-lines are again evacuated. The CLE is heated up to room temperature. Afterwards, potential small amounts of remaining water vapor is frozen out using an ethanol-dry ice bath for $4 \mathrm{~min}$ before the $\mathrm{CO}_{2}$ is then cryotransferred and collected in the MAN while water vapor is kept frozen in CLE by the ethanol-dry ice bath. In MAN, the sample $\mathrm{CO}_{2}$ is quantified manometrically after the valve towards the vacuum line is closed and the tube reached room temperature. Finally the $\mathrm{CO}_{2}$ is transferred to SAM and flame sealed in the glass tube. For ${ }^{14} \mathrm{C}$ analysis in the AMS laboratory, the glass vial is cracked in the gas interface system and the $\mathrm{CO}_{2}$ sample is injected into the AMS (MICADAS, University of Bern, Switzerland; Ruff et al. 2007; Szidat et al. 2014).

\section{CHARACTERIZATION}

To characterize the setup and procedure in terms of its oxidation efficiency, procedural blanks and accuracy, various standard and blank measurements have been carried out. For a first validation by comparison with other published DOC data, environmental ice samples from Piz Zupò and Fiescherhorn (both Swiss Alps; Jenk et al. 2006; Sodemann et al. 2006; Mariani et al. 2014) were analyzed.

\section{Oxidation Efficiency}

For determination of the oxidation efficiency, multiple standard solutions covering a range of concentrations were prepared from different organic substances using UPW for dissolution which had previously additionally been cleaned from DOC and IC in our photo-reactor as described earlier. The liquid solutions were then added with a syringe via a septum to the UV reactor containing the pre-oxidized water and then were oxidized following the procedure described earlier to quantify their carbon content. The efficiency was then calculated from the determined carbon yield of the initial substrate after subtraction of the oxidation blank which will be discussed in the next section. Using an initial setup with a fixed oxidation time of $45 \mathrm{~min}$; average oxidation efficiencies of $82 \%, 105 \%, 79 \%$, and $54 \%$ for oxalate, formate, phthalate and acetate were observed, respectively (Figure 4a). With installing the NDIR $\mathrm{CO}_{2}$ detector in-line in the modified setup (Figure 1) allowing for continuous monitoring of the oxidation progress, sample specific adjustment of the oxidation time became possible allowing reaching higher efficiencies of up to $90 \pm 6 \%$ (Figure 4b). However, the optimized, much longer oxidation times (up to $120 \mathrm{~min}$ ) limit sample throughput and are thus not favorable. Based on the study of photo-assisted Fenton-type processes for the degradation of phenol, $\mathrm{Fe}^{2+}$ and $\mathrm{H}_{2} \mathrm{O}_{2}$ was used to facilitate oxidation in a further improvement aimed at the reduction of the analytical time (Hsueh et al. 2005; Kušić et al. 2006). As described, $2 \mathrm{~mL}$ of 100 ppm $\mathrm{FeSO}_{4}$ and $1 \mathrm{~mL}$ of $50 \mathrm{mM}$ $\mathrm{H}_{2} \mathrm{O}_{2}$ solution were therefore added to the reactor at the beginning of the pre-cleaning step and an additional $1 \mathrm{~mL} \mathrm{H}_{2} \mathrm{O}_{2}$ right before the sample UV irradiation. As a result, 

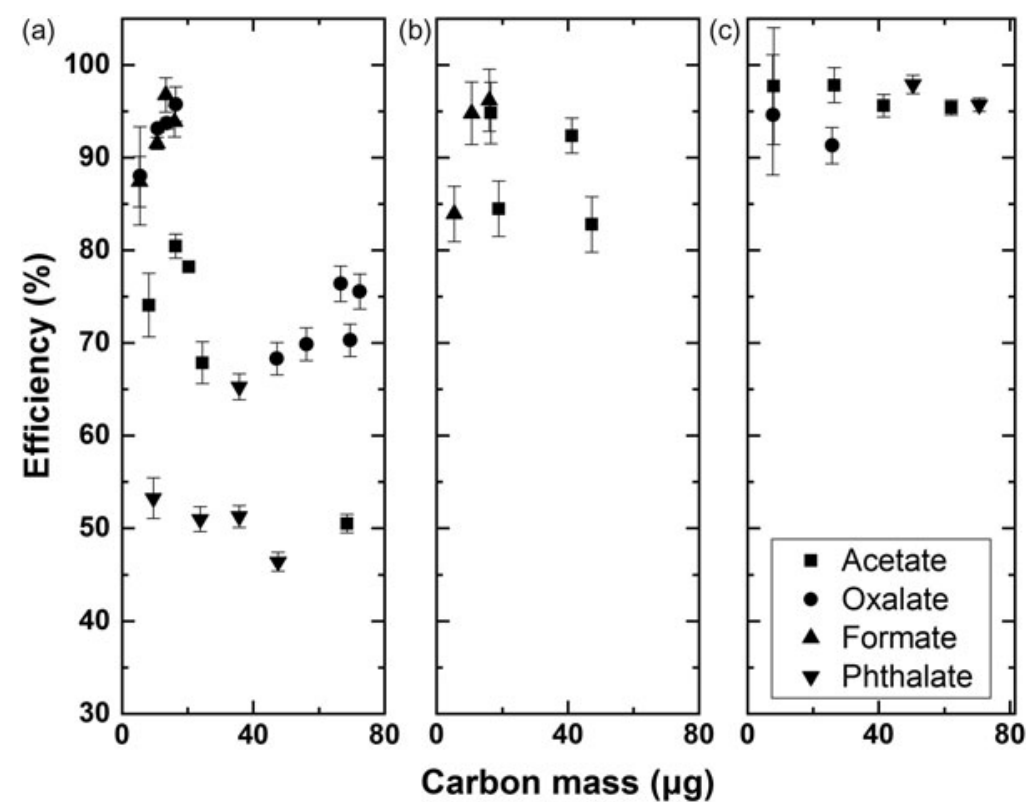

Figure 4 Oxidation efficiency for different organic compounds. (a) initial setup with fixed oxidation time at $45 \mathrm{~min}$; (b) modified setup allowing compound specific optimization of the oxidation time (60-120 min); (c) modified setup with added $\mathrm{Fe}^{2+}$ and $\mathrm{H}_{2} \mathrm{O}_{2}$ for a catalyzed oxidation reaction (20-30 $\left.\mathrm{min}\right)$.

the average oxidation efficiency was improved again significantly to $96 \pm 6 \%$ ( $n=8$, various compounds) while strongly shortened irradiation times of 20-30 min depending on the compound could be achieved (Figure 4c). This is an advancement compared to other existing systems for the analysis of DOC and its ${ }^{14} \mathrm{C}$ content (Table 1). With this setup optimized both for oxidation efficiency and irradiation time, the analysis of one blank and three samples can be performed per day.

\section{Standards and Blank}

We assume the oxidation step to be the most crucial step of the entire procedure since potential contaminations are oxidized and detected along with the sample. To determine the blank mass $\left(\mathrm{mC}_{\mathrm{OX}}\right)$ and the blank ${ }^{14} \mathrm{C}$ activity $\left(\mathrm{F}^{14} \mathrm{C}_{\mathrm{OX}}\right)$ of the oxidation step, solutions were prepared from the standard reference material (NIST Oxalic Acid II, SRM 4990C, $\mathrm{F}^{14} \mathrm{C}=1.3407 \pm$ 0.0005 ) and sodium acetate (Sigma-Aldrich, No. $71180, \mathrm{~F}^{14} \mathrm{C}=0.0018 \pm 0.0005$, Szidat et al. 2014) over a range of concentrations and with different $\mathrm{F}^{14} \mathrm{C}$ activity. In Figure 5, the ${ }^{14} \mathrm{C}$ results measured for these two standard samples are shown as a function of the carbon mass. Based on these values and assuming constant contamination, $\mathrm{mC}_{\mathrm{Ox}}$ and $\mathrm{F}^{14} \mathrm{C}_{\mathrm{OX}}$ can be estimated by applying isotopic mass balance calculations (Hwang and Druffel 2005). The resulting values for the oxidation blank are $\mathrm{mC}_{\mathrm{Ox}}=0.67 \pm 0.26 \mu \mathrm{g} \mathrm{C}$ with $\mathrm{F}^{14} \mathrm{C}_{\mathrm{OX}}=$ $0.76 \pm 0.18$ with the uncertainties being derived from a full error propagation including the analytical uncertainty for both, $\mathrm{mC}$ and $\mathrm{F}^{14} \mathrm{C}$. In reverse, when these values are now applied for a blank correction of the measured standards, good agreement within the uncertainties is found compared to the expected $\mathrm{F}^{14} \mathrm{C}$ values (Figure 5). This suggests a correction based on the determined blank values under the assumption of a constant 


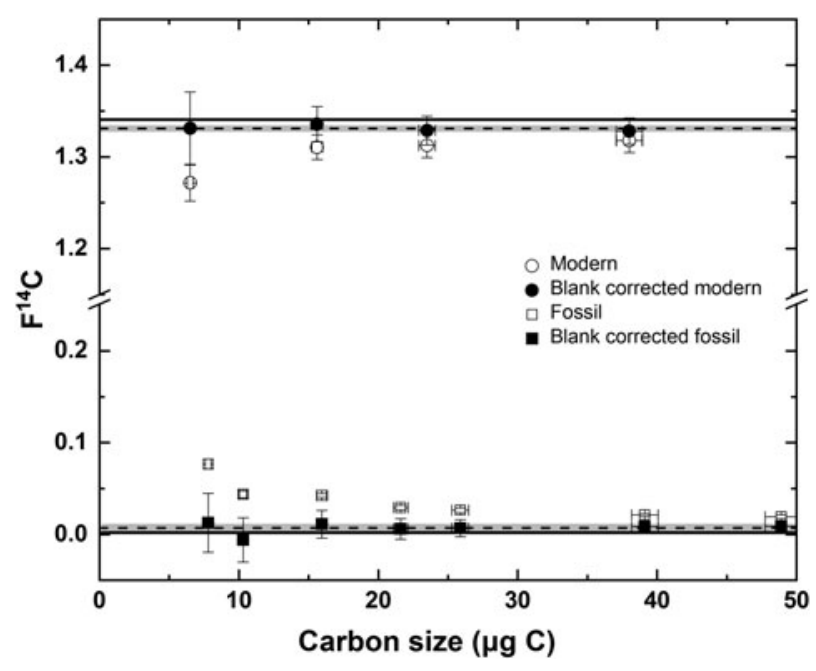

Figure $5 \quad \mathrm{~F}^{14} \mathrm{C}$ of radiocarbon standards before (open symbols) and after correction for the oxidation blank (black symbols) with analytical and fully propagated uncertainties $(1 \sigma)$, respectively. Solid horizontal lines indicate the reference values for a fossil standard with $\mathrm{F}^{14} \mathrm{C}=0.0018 \pm 0.0005$ (sodium acetate) and a modern standard with $\mathrm{F}^{14} \mathrm{C}=1.3407 \pm 0.0005$ (NIST Oxalic Acid II), respectively. Dashed lines indicate the here determined mean values ( $1 \sigma$ uncertainty band in gray) of $\mathrm{F}^{14} \mathrm{C}=0.007 \pm 0.006$ and $\mathrm{F}^{14} \mathrm{C}=1.331 \pm 0.003$ for the fossil and modern standard, respectively.

contamination is valid. As shown in Figure 5 it can be applied over a wide range of sample sizes, however it does result in an increase of the overall uncertainty for small samples $(<10 \mu \mathrm{g} \mathrm{C})$ due to the uncertainty of the blank.

Going one step further, the overall process blank including all pretreatment steps such as ice cutting, melting, and filtration was determined using frozen UPW for the simulation of blank ice (UPIce). As expected, this overall process blank was found to be higher in carbon mass and higher in variability compared to the above discussed oxidation blank alone (Figure 6). Measurements of 26 individual UPIce blanks resulted in a mean carbon mass of $\mathrm{mC}_{\mathrm{P}}=1.9$ $\pm 1.6 \mu \mathrm{g} \mathrm{C}(\mathrm{n}=26)$ with 8 samples giving masses below the detection limit $(0.5 \mu \mathrm{g} \mathrm{C}$; to calculate the mean, the oxidation blank value was considered in these cases). Due to the generally small carbon masses, only a few of these blanks could be measured for ${ }^{14} \mathrm{C}$ resulting in a mean $\mathrm{F}^{14} \mathrm{C}_{\mathrm{P}}=0.68 \pm 0.13(\mathrm{n}=7)$. To check the water quality, UPW from the water system have been measured routinely, also shown in Figure 6. Considering all the results shown in this figure, a trend toward higher blanks with increasing water/ice volumes can be observed, making it apparent that at least a fraction of the determined carbon mass and variability in $\mathrm{mC}_{\mathrm{P}}$ can be assigned to changing water quality. Similarly setup and method unrelated, a contribution from potential contamination occurring during the freezing process of the UPIce blocks cannot be excluded. With the current data set, a quantitative distinction of these different contribution factors is however not possible and both size and uncertainty of the determined overall process blank can be considered to be rather conservative estimates. Nevertheless, our method still performs excellently in terms of low carbon background if compared to other setups, with our values being at the low end (Table 1). 
Table 1 Performances of different DOC extraction setups for ice or non-saline water samples.

\begin{tabular}{|c|c|c|c|c|c|c|c|}
\hline Reference & Method & Sample/size & $\begin{array}{c}{ }^{14} \mathrm{C} \\
\text { analysis }\end{array}$ & $\begin{array}{l}\text { Oxidation } \\
\text { blank }\end{array}$ & Total blank & Efficiency $(\%)$ & $\begin{array}{l}\text { Oxidation } \\
\text { time (min) }\end{array}$ \\
\hline This study & $\mathrm{UV}\left(\mathrm{H}_{2} \mathrm{O}_{2}, \mathrm{Fe}^{2+}\right)$ & Ice $/ 350 \mathrm{~mL}$ & Yes & $0.67 \pm 0.26 \mu \mathrm{g} \mathrm{C}$ & $1.9 \pm 1.6 \mu \mathrm{g} \mathrm{C}$ & $96 \pm 6$ & 30 \\
\hline Federer et al. & $\mathrm{CFA}^{1}-\mathrm{UV}$ & Ice $/ \sim 1 \mathrm{~mL} / \mathrm{min}$ & No & - & $50 \mathrm{ppbC}$ & $86-139 *$ & 2 \\
\hline $\begin{array}{l}\text { May et al. } \\
\text { (2013) }\end{array}$ & UV & Ice $/ 300 \mathrm{~mL}$ & Yes & $1.9 \pm 0.2 \mu \mathrm{g} \mathrm{C}$ & $6 \pm 3 \mu \mathrm{g} \mathrm{C}$ & $81-96$ & 40 \\
\hline $\begin{array}{l}\text { Preunkert } \\
\text { et al. (2010) }\end{array}$ & UV & Ice $/ 4 \mathrm{~mL}$ & No & - & $25 \pm 1.5 \mathrm{ppbC}$ & $85-125^{*}$ & 10 \\
\hline $\begin{array}{l}\text { Steier et al. } \\
\text { (2013) }\end{array}$ & UV & Water $/ 1 \mathrm{~mL}$ & Yes & - & $1.10 .7 \mu \mathrm{g} \mathrm{C}$ & $64 \pm 17$ & 120 \\
\hline $\begin{array}{l}\text { Lang et al. } \\
\text { (2016) }\end{array}$ & $\mathrm{WCO}^{2}$ & Non-saline water/7 mL & Yes & - & $0.68-1.05 \mu \mathrm{g} \mathrm{C}$ & $87-128$ & 60 \\
\hline
\end{tabular}

${ }^{1}$ Continuous flow analysis, ${ }^{2}$ wet chemical oxidation, — no data available, ${ }^{*}$ TOC standard (phthalate) set as $100 \%$. 


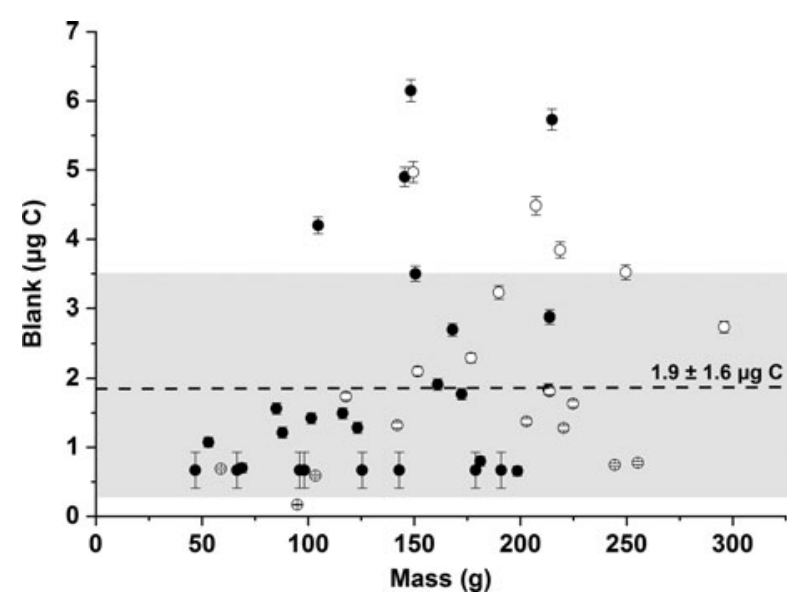

Figure 6 Process blank including all method steps. Open circles indicate blanks using ultra-pure water samples (UPW blank) and closed circles artificial ice blanks prepared by freezing ultra-pure water (UPIce blank). The UPIce blank mean is indicated by the dashed line with thel $\sigma$ uncertainty band in gray.

Considering the effect of blank correction on the uncertainty, the conventional approximation is that samples with a carbon content of around 5 times the blank mass still allows obtaining reliable results. In our case, this would require a minimal sample mass of $9.5 \mu \mathrm{g} \mathrm{C}$. Considering a maximum sample size of about $350 \mathrm{~mL}$, our setup can thus be expected to reliably allow analysis of samples with concentrations as low as $\sim 25 \mathrm{ppbC}\left(=25 \mu \mathrm{g} \mathrm{C} \mathrm{kg} \mathrm{kg}^{-1}\right.$ ice $)$. This makes our method applicable for the analysis of typical high-alpine ice core samples and potentially Greenland samples (Legrand et al. 2013b).

\section{Natural Ice Samples}

In order to apply the described setup and method to natural ice samples in a first attempt, sections of a 43-m-long ice core from Piz Zupò (3900 m asl, Swiss Alps), drilled in 2002 were selected. The high mean annual accumulation rate of $2.6 \pm 0.8 \mathrm{~m}$ w.e. (Sodemann et al. 2006) allows investigating the seasonal variation of DOC. Samples from a depth of $29-41 \mathrm{~m}$ (corresponding to the period of 1991-1995) that consisted of porous firn were cut and analyzed. Our results, however, show no clear seasonal DOC trend, but extremely high DOC concentrations of about $950-1400 \mathrm{ppbC}$ with depleted $\mathrm{F}^{14} \mathrm{C}$ values $(\sim 0.15-0.22)$ especially in the top part of this core, assigned to the years 1994-1995 AD. These high concentrations are unexpected based on available results of similar age from Col du Dôme (French Alps) with DOC values of around $200 \mathrm{ppbC}$ (Legrand et al. 2013b). Thus, contamination of this porous firn part of the core has to be assumed. This is supported by the fact that the observed DOC concentrations show significant increase with decreasing density of the firn. An estimate of the mean density at which bubbles are closed-off in the firn can be calculated (Martinerie et al. 1992, 1994) and is around $0.81 \mathrm{~kg} / \mathrm{L}$ for the conditions at Piz Zupò. With decreasing densities (i.e. depth), the open porous space in the firn increases and is connected to the atmosphere. Core sections from these depths thus do not contain enclosed bubbles but open pores connected to the ambient air allowing potential contaminants to diffuse into the core with the possibility of subsequent deposition. This process is active from the time of drilling, 
over the entire time of storage until final sample handling. The $\mathrm{F}^{14} \mathrm{C}$ results of around 0.2 give further indication of the contamination, pointing to a source being dead in ${ }^{14} \mathrm{C}$ if considering the expected $\mathrm{F}^{14} \mathrm{C}$ range of around 0.8 (May et al. 2013). We thus assume the contamination sources to be related to indoor (cold room) storage and packing material (e.g. outgassing plastic bags and isolation foams). Based on these first results, one should be very cautious when analyzing and interpreting DOC data from firn samples, at least if stored for a long time, since this source of contamination cannot be removed by decontamination procedures.

In a second attempt, we selected samples from the Fiescherhorn ice core using sections from greater depth and ice densities of around $0.9 \mathrm{~kg} / \mathrm{L}$ (i.e. solid ice samples). We analyzed samples from the period 1925-1936 AD, because annual mean DOC concentrations were previously reported for the Alps for that period (Legrand et al. 2013a). The average DOC concentration we found was $66 \pm 19 \mathrm{ppbC}$ with an $\mathrm{F}^{14} \mathrm{C}$ of $0.74 \pm 0.05(\mathrm{n}=9)$, which is in good agreement with the concentrations of $70 \mathrm{ppbC}$ at $\mathrm{Col}$ du Dôme (Legrand et al. 2013a). $\mathrm{F}^{14} \mathrm{C}$ values are comparable to the values we measured in the corresponding WIOC in the Fiescherhorn ice core $\left(\mathrm{F}^{14} \mathrm{C}=0.70 \pm 0.08\right)$.

\section{CONCLUSIONS}

We present a new setup for the analysis of DOC and its ${ }^{14} \mathrm{C}$ content. The comparison with other devices for ${ }^{14} \mathrm{C}$ analysis of DOC shows our setup performs excellently in terms of low carbon background with the advantage of higher carbon yields while keeping analysis time low. This was achieved thanks to sample treatment under inert gas conditions, a thorough decontamination procedure of the system prior to sample loading and an enhanced UV oxidation efficiency by taking advantage of the Fenton catalytic reaction. With the current setup, samples with DOC concentrations as low as $\sim 25$ ppbC can be reliably analyzed for ${ }^{14} \mathrm{C}$ when using the maximal applicable volume of $350 \mathrm{~mL}$ of ice. First analysis of samples from two Alpine ice cores (Fiescherhorn and Piz Zupò, Switzerland) resulted in values comparable to previous studies using different setups. Furthermore, this analysis also indicated the high risk of DOC contamination in firn samples, at least if stored for a longer period of time. In the near future, this system will allow increasing the number of available long-term DOC records covering the preindustrial period, which is an important constraint for emission estimates used to simulate aerosol forcing in current climate models.

\section{ACKNOWLEDGMENTS}

We thank the Laboratory for the Analysis of Radiocarbon with AMS (LARA), especially Gary Salazar, for support with radiocarbon measurements. Also we thank Steven Beaupré for his sharing of knowledge and experience with DOC systems resulting in invaluable technical advice and Alexander Vogel for helping with ice cutting in the cold room.

\section{REFERENCES}

Beaupré SR, Druffel ER, Griffin S. 2007. A low-blank photochemical extraction system for concentration and isotopic analyses of marine dissolved organic carbon. Limnology and Oceanography: Methods 5(6):174-184.

Eichler A, Gramlich G, Kellerhals T, et al. 2015. Pb pollution from leaded gasoline in South America in the context of a 2000-year metallurgical history. Science Advances 1(2):e1400196.

Eichler A, Tobler L, Eyrikh S, et al. 2012. Three centuries of eastern European and altai lead emissions recorded in a belukha ice core. Environmental Science \& Technology 46(8): 4323-4330. 
Federer U, Kaufmann PR, Hutterli MA, et al. 2008. Continuous flow analysis of total organic carbon in polar ice cores. Environmental Science \& Technology 42(21):8039-8043.

Gelencsér A,May B, Simpson D, et al. 2007. Source apportionment of pm 2.5 organic aerosol over Europe: Primary/secondary, natural/anthropogenic, and fossil/biogenic origin. Journal of Geophysical Research: Atmospheres 112(D23S04).

Hsueh C, Huang Y, Wang C, et al. 2005. Degradation of azo dyes using low iron concentration of fenton and fenton-like system. Chemosphere 58(10): 1409-1414.

Hwang J, Druffel ER. 2005. Blank correction for $\Delta^{14} \mathrm{C}$ measurements in organic compound classes of oceanic particulate matter. Radiocarbon 47(1): 75-87.

Jenk T, Szidat S, Schwikowski M, et al. 2006. Radiocarbon analysis in an alpine ice core: record of anthropogenic and biogenic contributions to carbonaceous aerosols in the past (1650-1940). Atmospheric Chemistry and Physics 6(12): 5381-5390.

Jenk TM, Rubino M, Etheridge D, et al. 2016. A new set-up for simultaneous high-precision measurements of $\mathrm{CO}_{2}, \delta^{13} \mathrm{C}-\mathrm{CO}_{2}$ and $\delta^{18} \mathrm{O}-\mathrm{CO}_{2}$ on small ice core samples. Atmospheric Measurement Techniques 9(8):3687-3706.

Jenk TM, Szidat S, Bolius D, et al. 2009. A novel radiocarbon dating technique applied to an ice core from the Alps indicating Late Pleistocene ages. Journal of Geophysical Research: Atmospheres 114(D14305).

Jenk TM, Szidat S, Schwikowski $M$, et al. 2007. Microgram level radiocarbon $\left({ }^{14} \mathrm{C}\right)$ determination on carbonaceous particles in ice. Nuclear Instruments and Methods in Physics Research B 259(1):518-525.

Kušić H, Koprivanac N, Božić AL, et al. 2006. Photoassisted fenton type processes for the degradation of phenol: a kinetic study. Journal of Hazardous Materials 136(3):632-644.

Lang SQ, McIntyre CP, Bernasconi SM, et al. 2016. Rapid ${ }^{14} \mathrm{C}$ analysis of dissolved organic carbon in non-saline waters. Radiocarbon 58(3):505-515.

Legrand M, Preunkert S, Jourdain B, et al. 2013a. Water-soluble organic carbon in snow and ice deposited at alpine, greenland, and antarctic sites: a critical review of available data and their atmospheric relevance. Climate of the Past 9(5):2195-2211.

Legrand M, Preunkert S, May B, et al. 2013b. Major 20th century changes of the content and chemical speciation of organic carbon archived in alpine ice cores: implications for the long-term change of organic aerosol over Europe. Journal of Geophysical Research: Atmospheres 118(9):3879-3890.

Libby WF. 1954. Chicago radiocarbon dates V. Science 120(3123):733-742.

Mariani I, Eichler A, Jenk T, et al. 2014. Temperature and precipitation signal in two alpine ice cores over the period 1961-2001. Climate of the Past 10(3):1093-1108.

Martinerie P, Lipenkov VY, Raynaud D, et al. 1994. Air content paleo record in the vostok ice core (Antarctica): a mixed record of climatic and glaciological parameters. Journal of Geophysical Research: Atmospheres 99(D5):10565-10576.

Martinerie P, Raynaud D, Etheridge DM, et al. 1992. Physical and climatic parameters which influence the air content in polar ice. Earth and Planetary Science Letters 112(1-4):1-13.

May B, Wagenbach D, Hoffmann H, et al. 2013. Constraints on the major sources of dissolved organic carbon in alpine ice cores from radiocarbon analysis over the bomb-peak period. Journal of Geophysical Research: Atmospheres 118(8):3319-3327.

May BL. 2009. Radiocarbon microanalysis on ice impurities for dating of alpine glaciers $[\mathrm{PhD}$ thesis]. University of Heidelberg.

Pio C, Legrand M, Oliveira T, et al. 2007. Climatology of aerosol composition (organic versus inorganic) at nonurban sites on a west-east transect across Europe. Journal of Geophysical Research: Atmospheres 112(D23S02).

Preunkert S, Legrand M, Stricker P, et al. 2010. Quantification of dissolved organic carbon at very low levels in natural ice samples by a UVinduced oxidation method. Environmental Science \& Technology 45(2):673-678.

Reimer PJ, Bard E, Bayliss A, et al. 2013. IntCal13 and Marine13 radiocarbon age calibration curves $0-50,000$ years cal BP. Radiocarbon 55(4):1869-1887.

Ruff M, Wacker L, Gäggeler H, et al. 2007. A gas ion source for radiocarbon measurements at $200 \mathrm{KV}$. Radiocarbon 49(2):307-314.

Schindler J. 2017. An extraction system for radiocarbon microanalysis of dissolved organic carbon in glacier ice [ $\mathrm{PhD}$ thesis]. Universität Bern.

Schwikowski M, Brütsch S, Gäggeler $\mathrm{H}$, et al. 1999a. A high-resolution air chemistry record from an alpine ice core: Fiescherhorn glacier, Swiss Alps. Journal of Geophysical Research: Atmospheres 104(D11):13709-13719.

Schwikowski M, Döscher A, Gäggeler H, et al. 1999b. Anthropogenic versus natural sources of atmospheric sulphate from an alpine ice core. Tellus B: Chemical and Physical Meteorology 51(5):938-951.

Sigl M, Jenk TM, Kellerhals T, et al. 2009. Towards radiocarbon dating of ice cores. Journal of Glaciology 55(194):985-996.

Singer GA, Fasching C, Wilhelm L, et al. 2012. Biogeochemically diverse organic matter in alpine glaciers and its downstream fate. Nature Geoscience 5(10):710.

Sodemann H, Palmer A, Schwierz C, et al. 2006. The transport history of two saharan dust events archived in an alpine ice core. Atmospheric Chemistry and Physics 6(3):667-688. 
Steier P, Fasching C, Mair K, et al. 2013. A new UV oxidation setup for small radiocarbon samples in solution. Radiocarbon 55(2): 373-382.

Stuiver M, Suess HE. 1966. On the relationship between radiocarbon dates and true sample ages. Radiocarbon 8:534-540.

Szidat S, Jenk T, Gäggeler H, et al. 2004. Theodore, a two-step heating system for the EC/OC determination of radiocarbon $\left({ }^{14} \mathrm{C}\right)$ in the environment. Nuclear Instruments and Methods in Physics Research B 223:829-836.

Szidat S, Jenk TM, Synal HA, et al. 2006. Contributions of fossil fuel, biomass-burning, and biogenic emissions to carbonaceous aerosols in Zurich as traced by ${ }^{14} \mathrm{C}$. Journal of Geophysical Research: Atmospheres 111(D07206).
Szidat S, Salazar GA, Vogel E, et al. $2014 .{ }^{14} \mathrm{C}$ analysis and sample preparation at the new Bern laboratory for the analysis of radiocarbon with AMS (LARA). Radiocarbon 56(2):561-566.

Thompson LG, Davis ME, Mosley-Thompson E, et al. 1998. A 25, 000-year tropical climate history from bolivian ice cores. Science 282(5395): 1858-1864.

Uglietti C, Zapf A, Jenk TM, et al. 2016. Radiocarbon dating of glacier ice: overview, optimisation, validation and potential. The Cryosphere 10(6):3091-3105.

Zhang Y, Perron N, Ciobanu V, et al. 2012. On the isolation of oc and ec and the optimal strategy of radiocarbon-based source apportionment of carbonaceous aerosols. Atmospheric Chemistry and Physics 12(22):10841-10856. 